\title{
Porfyrisykdommer i Norge
}

BAKGRUNN Porfyri er fellesbetegnelse på en gruppe hovedsakelig arvelige sykdommer som forårsakes av defekt hemesyntese. Sykdommene har et variert og til dels overlappende spekter av symptomer og funn. De vanligste formene for porfyri er porphyria cutanea tarda, akutt intermitterende porfyri og erytropoetisk protoporfyri. Formålet med denne studien var å gi en oversikt over blant annet forekomst og sykdomsmanifestasjon ved porfyrisykdommer i Norge.

MATERIALE OG METODE Informasjon om alle pasienter registrert ved Nasjonalt kompetansesenter for porfyrisykdommer (NAPOS) frem til 2012 ble brukt til å estimere prevalens og insidens av porfyrier i Norge. Forekomst av symptomer, utløsende årsaker og oppfølgingsrutiner ble innhentet fra Norsk porfyriregister, som omfatter $70 \%$ av norske personer registrert med porfyri ved NAPOS.

RESULTATER Prevalensen av porphyria cutanea tarda og akutt intermitterende porfyri var henholdsvis ca. $10: 100000$ og $4: 100$ 000. Total insidens for alle porfyrisykdommene var ca. 0,5-1:100 000 per år. Den diagnostiske forsinkelsen, dvs. tid fra symptomdebut til diagnose, var på 1-17 år, avhengig av porfyrisykdom. Det var stor variasjon i hvor hyppig pasienter med de forskjellige porfyrisykdommene gikk til kontroll hos lege.

FORTOLKNING Prevalensen av akutt intermitterende porfyri og porphyria cutanea tarda synes å være høyere i Norge enn i de fleste andre land. Data fra Norsk porfyriregister gjør det mulig å synliggjøre forskjeller i behandling og oppfølging av porfyripasienter og kan brukes til å initiere nødvendige tiltak.

Porfyri er fellesbetegnelse på en gruppe sjeldne, hovedsakelig arvelige sykdommer som skyldes unormal aktivitet i de forskjellige enzymene i hemesyntesen (1). Diagnostikk ved symptomgivende sykdom er basert på funn av karakteristiske mønstre av hemeforstadier i urin, feces og blod. For flere av sykdommene er imidlertid både symptomer og biokjemiske funn overlappende, noe som gjør diagnostikken utfordrende.

Noen av porfyrisykdommene kan gi potensielt livstruende akutte anfall karakterisert av sterke magesmerter, nevrologiske og psykiske symptomer, mens andre gir kutane symptomer i form av vesikler og sårbar hud eller smerter i soleksponert hud (tab 1). To av sykdommene kan gi både akutte anfall og hudsymptomer. De fleste porfyrisykdommer har lav klinisk penetrans (2). De to hyppigst forekommende porfyrisykdommene, porphyria cutanea tarda og akutt intermitterende porfyri, arves autosomalt dominant. Porphyria cutanea tarda forekommer i tillegg i en sporadisk, ikkearvelig form (3).

Kunnskap om og erfaring med sjeldne diagnoser som porfyrisykdommene vil naturlig nok ofte være begrenset blant helsepersonell. Spesielt akutte porfyrisykdommer er differensialdiagnoser til andre langt hyppigere forekommende diagnoser, for eksempel appendisitt og ulike nevrologiske sykdommer. Pasientene kan derfor oppleve langvarig utredning før de får korrekt diagnose. Ved akutte porfyrisykdommer er tid- lig og riktig diagnose spesielt viktig, fordi veiledning om trygge og utrygge legemidler og levevaner kan bidra til å unngå akutte anfall både hos dem som har hatt anfall tidligere og hos genetisk disponerte individer som ikke har utviklet symptomer (4-6).

De akutte porfyrisykdommene har tidligere vært omtalt i Tidsskriftet $(7,8)$, men som for mange andre sjeldne sykdommer finnes det få systematiske studier basert på større pasientpopulasjoner. Målet med denne studien var å bruke informasjon om personer med porfyrisykdommer registrert ved Nasjonalt kompetansesenter for porfyrisykdommer (NAPOS) og data fra Norsk porfyriregister til å gi en oversikt over porfyrisykdommene i Norge, med vekt på insidens, prevalens, tid fra symptomdebut til diagnose, oppfølgingsrutiner og livskvalitet.

\section{Materiale og metode}

NAPOS har det overordnede ansvaret for diagnostikk av porfyrisykdommene og diagnostiserer nær alle tilfeller i Norge. Da kompetansesenteret ble etablert i 1999, ble det tatt kontakt med andre laboratorier som drev med porfyridiagnostikk, og det ble innhentet informasjon om pasienter diagnostisert ved disse.

Data om kjønn, alder, bosted og diagnose for alle personer registrert ved NAPOS inntil 2012 ble brukt til å estimere prevalens og insidens av de forskjellige porfyrisykdommene. Diagnosene ble stilt i henhold til diagnostiske algoritmer som beskrevet av Bad-

\author{
Mira Mykletun \\ mira_mykletun@hotmail.com \\ Aasne Karine Aarsand \\ Egil Støle \\ Jørild Haugen Villanger \\ Mette Christophersen Tollånes \\ Carl Baravelli \\ Sverre Sandberg \\ Nasjonalt kompetansesenter \\ for porfyrisykdommer (NAPOS) \\ Laboratorium for klinisk biokjemi \\ Haukeland universitetssykehus \\ e-fig 1 og e-fig 4 finnes i Tidsskriftets elektroniske \\ utgaver
}

Engelsk oversettelse på www.tidsskriftet.no

\section{HOVEDBUDSKAP}

Porfyrisykdommer er sjeldne, det diagnostiseres ca. 40-60 nye tilfeller per år

Tid fra symptomdebut til diagnose varierte fra ett til 17 år, avhengig av porfyrisykdom

Norsk porfyriregister gjør det mulig å følge trender i diagnostikk, kontroll og behandling av denne pasientgruppen 
Tabell 1 Oversikt over symptomer, arvegang og forekomst av porfyrisykdommer med 10 eller flere registrerte tilfeller ved Nasjonalt kompetansesenter for porfyrisykdommer (NAPOS) frem til 2012

$\begin{array}{llc}\text { Diagnose } & \text { Antall } \\ \text { Symptomersoner }\end{array}$

\begin{tabular}{|c|c|c|c|}
\hline \multicolumn{4}{|l|}{ Akutte porfyrier } \\
\hline Akutt intermitterende porfyri & Akutte anfall & $\begin{array}{l}\text { Autosomalt } \\
\text { dominant }\end{array}$ & 326 \\
\hline Symptomgivende ${ }^{1}$ & & & 189 \\
\hline Prediktivt påvist ${ }^{2}$ & & & 137 \\
\hline Hereditær koproporfyri & $\begin{array}{l}\text { Akutte anfall og/eller foto- } \\
\text { sensitivitet i form av sårbar } \\
\text { hud og blemmer }\end{array}$ & $\begin{array}{l}\text { Autosomalt } \\
\text { dominant }\end{array}$ & 10 \\
\hline Porphyria variegata & $\begin{array}{l}\text { Akutte anfall og/eller foto- } \\
\text { sensitivitet i form av sårbar } \\
\text { hud og blemmer }\end{array}$ & $\begin{array}{l}\text { Autosomalt } \\
\text { dominant }\end{array}$ & 30 \\
\hline
\end{tabular}

\section{Kutane porfyrier}

\begin{tabular}{|c|c|c|c|}
\hline Porphyria cutanea tarda & $\begin{array}{l}\text { Fotosensitivitet i form } \\
\text { av sårbar hud og blemmer }\end{array}$ & $\begin{array}{l}\text { Autosomalt } \\
\text { dominant/sporadisk }\end{array}$ & 576 \\
\hline Symptomgivende ${ }^{1}$ & & & 509 \\
\hline Prediktivt påvist ${ }^{2}$ & & & 67 \\
\hline Erytropoetisk protoporfyri & $\begin{array}{l}\text { Akutt fotosensitivitet i form } \\
\text { av smerter i huden }\end{array}$ & $\begin{array}{l}\text { Autosomalt } \\
\text { recessivt }\end{array}$ & 32 \\
\hline Totalt & & & 974 \\
\hline
\end{tabular}

${ }^{1}$ Har eller har hatt symptomer på sin porfyrisykdom

2 Påvist genetisk disposisjon for porfyrisykdom uten å ha hatt symptomer

Antall akutt intermitterende porfyri Porphyria cutanea tarda $\quad$ Alle diagnoser

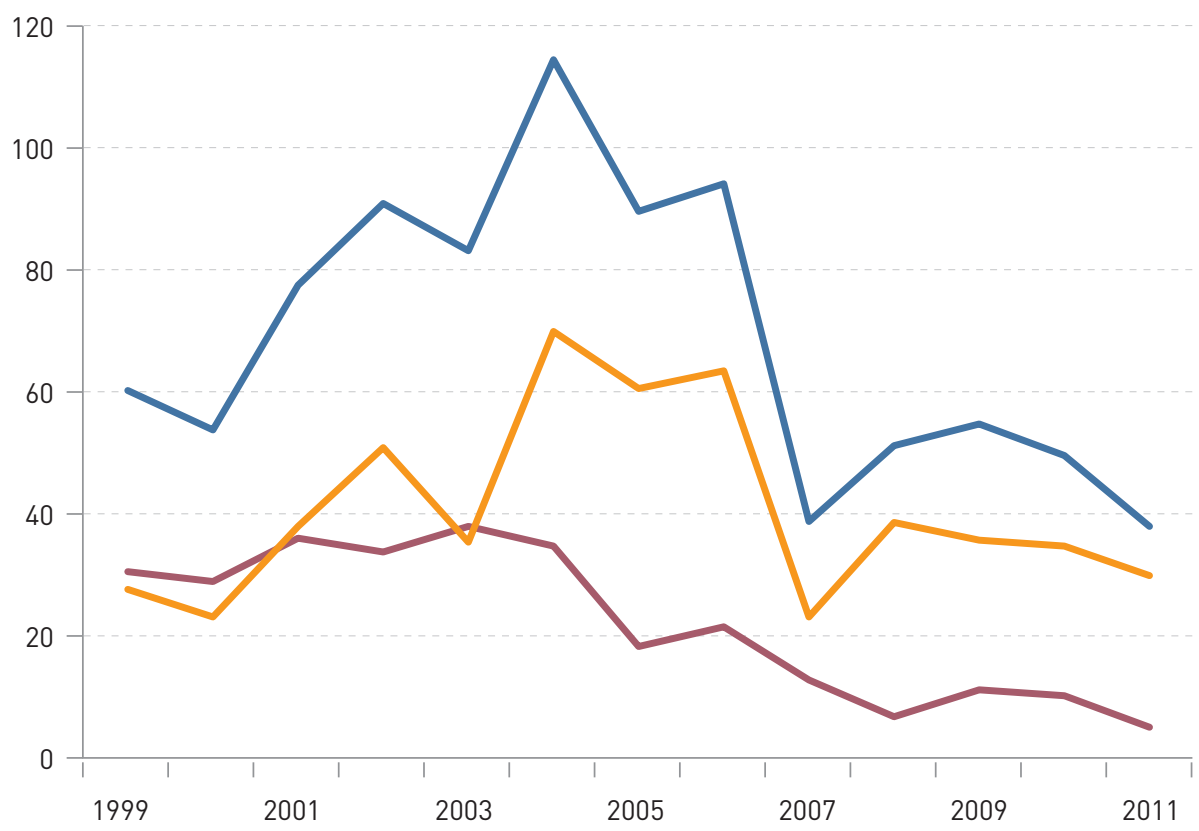

Figur 2 Antall nye diagnoser per år ved Nasjonalt kompetansesenter for porfyrisykdommer (NAPOS) i tidsrommet 1999-2011 ( $n=896$ ). Alle diagnoser omfatter akutt intermitterende porfyri, porphyria cutanea tarda, porphyria variegata, hereditær koproporfyri og erytropoetisk protoporfyri minton og medarbeidere (4), basert på porfyrirelaterte biokjemiske analyser utført ved Laboratorium for klinisk biokjemi, Haukeland universitetssykehus. DNA-analyser ble utført ved Senter for medisinsk genetikk og molekylærmedisin ved sykehuset.

Det blir i artikkelen skilt mellom symptomgivende og prediktivt påviste porfyrisykdommer. «Symptomgivende» brukes der personen har eller har hatt symptomer på porfyrisykdom. «Prediktivt påvist» brukes der personen har fått påvist genetisk disposisjon for porfyrisykdom uten å ha hatt symptomer.

Informasjon om siste registrerte bosted ble innhentet fra det sentrale folkeregisteret (per november 2011) og befolkningstall fra Statistisk sentralbyrå (per oktober 2011). Døde er ikke inkludert i de oppgitte tall for prevalens.

Norsk porfyriregister er et nasjonalt medisinsk kvalitetsregister basert på systematisk innsamling av pasientutfylte spørreskjemaer. Alle som er registrert ved NAPOS med diagnosene porphyria cutanea tarda, akutt intermitterende porfyri, porphyria variegata, hereditær koproporfyri og erytropoetisk protoporfyri og personer med prediktivt påvist arveanlegg for akutte porfyrisykdommer inviteres til å delta.

Da registeret ble opprettet i 2002, ble et spørreskjema sendt til alle med disse diagnosene. Etter den tid er invitasjon og spørreskjema blitt sendt ut gjennom behandlende lege eller genetisk veileder i forbindelse med førstegangs kontakt. Deltakerne får et oppfølgingsskjema ett eller to år etter første spørreskjema, deretter hvert fjerde år.

Totalt 680 personer $(70 \%$ av de inviterte), 370 kvinner og 310 menn, var registrert i Norsk porfyriregister per februar 2012. Opplysninger om symptomer, utløsende faktorer og feilbehandling er hentet fra det første spørreskjemaet. Data på kontroll- og oppfølgingsrutiner og livskvalitet ble hentet ut fra det sist besvarte spørreskjemaet. De fleste spørsmålene hadde forhåndsdefinerte svaralternativer med mulighet for fritekst. Informasjon om livskvalitet er hentet fra et ikke-standardisert enkeltspørsmål i spørreskjemaene (e-fig 1). Ulikheter i kontroll- og oppfølgingsrutiner for deltakere som hadde hatt porphyria cutanea tarda eller akutt intermitterende porfyri $i$ fire år eller mer $(\mathrm{n}=370)$ ble undersøkt.

Deskriptive analyser og enkle statistiske tester ble utført ved hjelp av SPSS versjon 18.0. Khikvadrattest ble brukt for å undersøke om det var signifikante forskjeller mellom kjønnene når det gjaldt symptomer og utløsende faktorer. P-verdier $<0,05$ ble ansett som statistisk signifikante. PX-Map (2009, Statistisk sentralbyrå, Oslo) ble brukt til å lage prevalenskart. 
Norsk porfyriregister har konsesjon fra Datatilsynet, og studien har godkjenning fra regional komité for medisinsk og helsefaglig forskningsetikk (REK Vest).

\section{Resultater}

Insidens og prevalens

I perioden 2000-04 ble det stilt et økende antall porfyridiagnoser per år (fig 2), spesielt porphyria cutanea tarda og prediktivt påvist akutt intermitterende porfyri økte sammenliknet med tidligere år. Fra 2003 til 2006 var det også en markant økning i antall tilfeller av prediktivt påvist porphyria cutanea tarda (ikke vist). I perioden 1999-2011 ble også de sjeldnere diagnosene hereditær koproporfyri og porphyria variegata påvist hyppigere enn tidligere. De siste fem årene har totalt antall nye tilfeller av porfyrisykdom stabilisert seg med en årlig insidens på rundt 0,5-1:100 000 .

Porphyria cutanea tarda er den hyppigst forekommende porfyrisykdommen i Norge, med totalt 576 registrerte tilfeller (tab 1), hvorav $12 \%$ er prediktivt påvist uten at pasienten har hatt symptomer. Tilsvarende tall for akutt intermitterende porfyri er 326 og $42 \%$.

Prevalensen ble beregnet til ca. 10:100 000 for symptomgivende porphyria cutanea tarda og til 4:100 000 for symptomgivende akutt intermitterende porfyri. Dersom personer med prediktivt påvist genetisk disposisjon ble inkludert, var den samlede prevalensen ca. 12:100 000 for porphyria cutanea tarda og ca. $7: 100000$ for akutt intermitterende porfyri.

Fylkesvis beregning av den samlede prevalensen av disse to porfyrisykdommene viste store geografiske forskjeller (fig 3). Av personene med porphyria cutanea tarda som var genetisk undersøkt $(\mathrm{n}=458)$, hadde 182 sporadisk og 276 arvelig form av sykdommen.

\section{Diagnostisk forsinkelse}

Median alder ved symptomdebut var 54 år ved porphyria cutanea tarda, 23 år ved akutt intermitterende porfyri og to år ved erytropoetisk protoporfyri. Median diagnostisk forsinkelse var ett år ved porphyria cutanea tarda, fire år ved akutt intermitterende porfyri og 17 år ved erytropoetisk protoporfyri.

Totalt $89 \%$ av deltakerne med porphyria cutanea tarda og $54 \%$ av dem med akutt intermitterende porfyri ble diagnostisert innen fem år etter symptomdebut (e-fig 4). $13 \%$ av deltakerne med akutt intermitterende porfyri og $36 \%$ av deltakerne med erytropoetisk protoporfyri rapporterte en diagnostisk forsinkelse på mer enn 20 år. Særlig deltakere med erytropoetisk protoporfyri $(54 \%)$, men også deltakere med akutt intermitterende porfyri (37\%) rapporterte om det de selv mente var feilbehand-

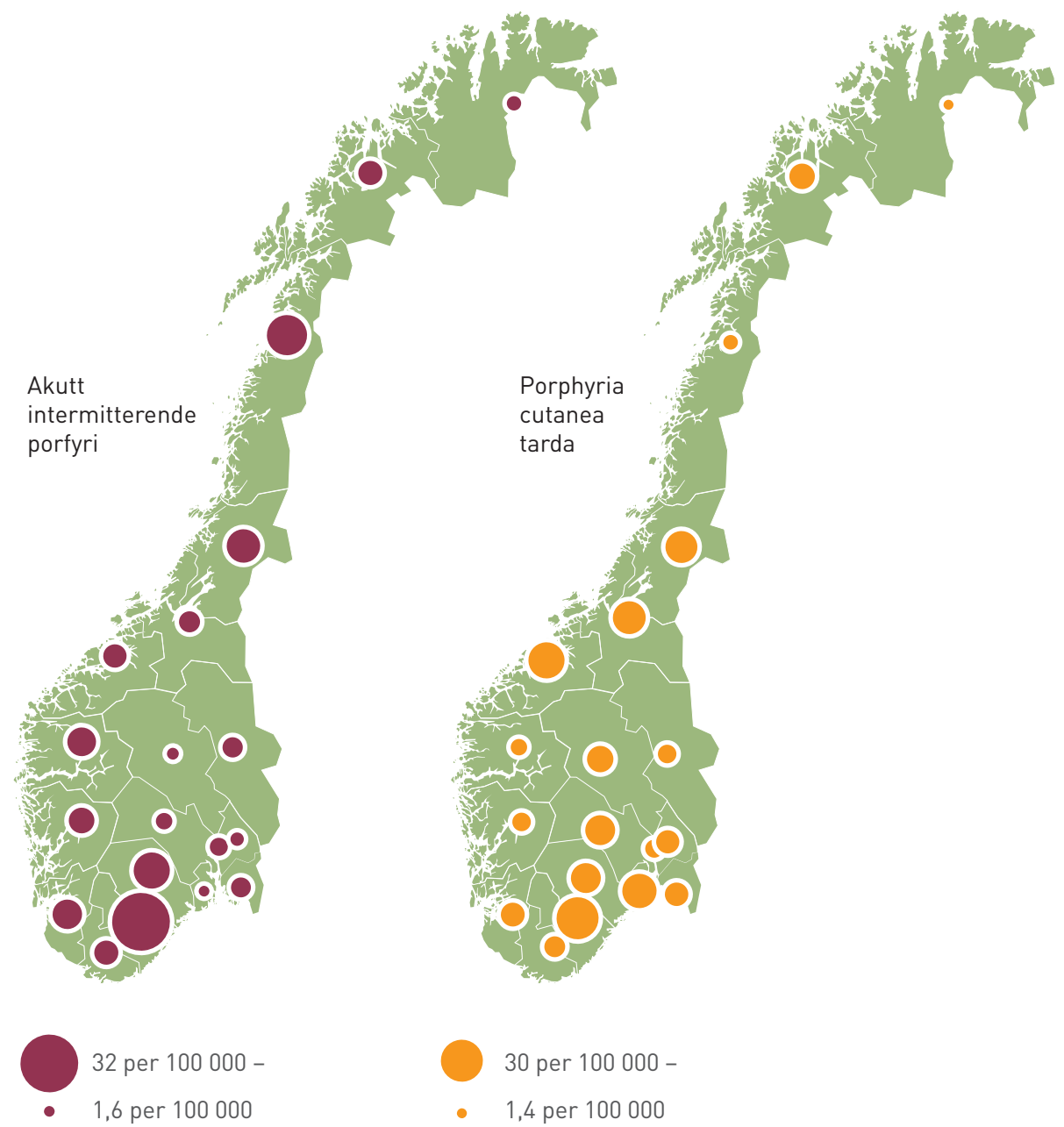

Figur 3 Fylkesvis prevalens per 100000 innbyggere av akutt intermitterende porfyri (n=323) og porphyria cutanea tarda ( $n=570$ ) registrert ved Nasjonalt kompetansesenter for porfyrisykdommer (NAPOS) per 31.12. 2011, inkludert personer som har prediktivt påvist genetisk disposisjon, men som ikke har hatt symptomer

ling før diagnosen ble stilt. En mindre andel av gruppen med porphyria cutanea tarda rapporterte om feilbehandling $(20 \%)$.

\section{Symptomer og utløsende faktorer}

Hos deltakerne med akutt intermitterende porfyri var psykisk stress $(63 \%)$ og fysiske påkjenninger (50\%) de faktorene som ble oppgitt som anfallsutløsende av flest. Deretter fulgte medisiner (40\%), søvnmangel $(37 \%)$, alkohol (31\%), arbeidsmiljø (27\%), sult $(27 \%)$, andre sykdommer $(25 \%)$ og mat $(22 \%)$. En større andel kvinner enn menn rapporterte at fysiske påkjenninger $(p=0,029)$ eller psykisk stress $(p=0,042)$ hadde vært en utløsende faktor. Menstruasjon og p-pillebruk var oppgitt som utløsende faktor hos henholdsvis $22 \%$ og $18 \%$ av kvinnene.

Porphyria cutanea tarda ble hos ca. $20 \%$ av pasientene utløst av alkohol, hos ca. $10 \%$ av leversykdom eller jerntilskudd, mens $40 \%$ av kvinnene rapporterte at symptomene ble utløst av østrogener.

Forekomst av symptomer rapportert til
Norsk porfyriregister ved de tre hyppigste porfyrisykdommene er oppgitt $i$ tabell 2 . Det ble ikke funnet signifikante forskjeller mellom kjønnene.

\section{Poliklinisk kontroll og oppfølging}

Det var store forskjeller mellom de ulike diagnosene når det gjaldt hyppighet av legekontroll. Andelen som aldri gikk til kontroll for sin porfyrisykdom var $94 \%$ hos deltakere med prediktivt påvist akutt intermitterende porfyri, $56 \%$ ved symptomgivende akutt intermitterende porfyri og $33 \%$ hos porphyria cutanea tarda. Andelen deltakere som gikk til en eller flere kontroller i året var $42 \%$ for akutt intermitterende porfyri og $58 \%$ for porphyria cutanea tarda.

\section{Livskvalitet}

Omtrent halvparten av deltakerne med symptomgivende akutt intermitterende porfyri og porphyria cutanea tarda rapporterte om nedsatt livskvalitet (e-fig 1). For erytropoetisk protoporfyri var andelen noe høyere. 
Tabell 2 Forekomst av symptomer rapportert til Norsk porfyriregister ved akutt intermitterende porfyri, porphyria cutanea tarda og erytropoetisk protoporfyri

\begin{tabular}{|c|c|c|c|c|c|}
\hline \multicolumn{2}{|c|}{$\begin{array}{l}\text { Akutt intermitterende porfyri } \\
\qquad(n=134)\end{array}$} & \multicolumn{2}{|c|}{$\begin{array}{l}\text { Porphyria cutanea tarda } \\
\qquad(\mathrm{n}=379)\end{array}$} & \multicolumn{2}{|c|}{$\begin{array}{l}\text { Erytropoetisk protoporfyri } \\
\qquad(\mathrm{n}=28)\end{array}$} \\
\hline $\begin{array}{l}\text { Symptomer opplevd } \\
\text { ved akutte anfall }\end{array}$ & $\begin{array}{l}\text { Pro- } \\
\text { sent }\end{array}$ & $\begin{array}{l}\text { Fotosensitivitet i form av } \\
\text { sårbar hud og blemmer }\end{array}$ & $\begin{array}{l}\text { Pro- } \\
\text { sent }\end{array}$ & $\begin{array}{l}\text { Fotosensitivitet i form } \\
\text { av smerter i huden }\end{array}$ & $\begin{array}{l}\text { Pro- } \\
\text { sent }\end{array}$ \\
\hline Kraftige magesmerter & 93 & Blemmer & 96 & $\begin{array}{l}\text { Brennende/ } \\
\text { stikkende smerter }\end{array}$ & 96 \\
\hline Tretthet & 72 & Sår/skjør hud & 86 & Rød/hoven hud & 86 \\
\hline Mørk/rødfarget urin & 64 & Mørk/rødfarget urin & 55 & Sår/skorper & 50 \\
\hline Muskelverk & 63 & Unormal hårvekst & 33 & Blemmer & 32 \\
\hline Muskelsvakhet & 59 & $\emptyset \mathrm{kt}$ pigmentering & 30 & & \\
\hline Hjertebank & 53 & & & & \\
\hline Hodepine & 52 & & & & \\
\hline Oppkast & 47 & & & & \\
\hline Obstipasjon & 46 & & & & \\
\hline Psykiske symptomer & 40 & & & & \\
\hline Nedsatt følelse & 39 & & & & \\
\hline Lammelser & 26 & & & & \\
\hline
\end{tabular}

\section{Diskusjon}

Etter opprettelsen av NAPOS i 1999 økte antallet personer diagnostisert med porfyrisykdommer i Norge fra ca. 10-20 per år før 1999 til et maksimum på 110 i 2004. Tallene fra før 1999 er usikre, da de er basert på opplysninger fra ulike sykehus i Norge. Også de sjeldnere diagnosene er blitt hyppigere påvist enn tidligere. Økningen skyldes sannsynligvis bedre diagnostiske metoder, økt oppmerksomhet omkring og større kunnskap om porfyrisykdommene samt effekt av familieutredninger.

Flere av de nye tilfellene av porphyria variegata og hereditær koproporfyri var endring av gamle porfyridiagnoser ved hjelp av nye biokjemiske og genetiske undersøkelser. I samme periode ble en del personer som tidligere hadde fått porfyridiagnose, «fratatt» denne ettersom det viste seg at den var basert på feiltolking av analyseresultater.

Da porfyrisykdommene er sjeldne, finnes det lite gode data på prevalens. Det kan også være store forskjeller i prevalens fra populasjon til populasjon eller mellom geografiske områder, blant annet på grunn av grunnleggereffekter (founder effects).

Porphyria cutanea tarda er den hyppigst forekommende porfyrisykdommen i de fleste populasjoner (1). I vår studie var det en pre- valens tilsvarende det som er rapportert fra Sverige (10:100 000) (9), men høyere prevalens enn for Storbritannia $(4: 100$ 000) (4). I de fleste populasjoner utgjør den arvelige formen for porphyria cutanea tarda rundt $25 \%$ av tilfellene (10-13). I vår studie hadde vi en vesentlig større andel arvelige tilfeller $(60 \%)$. En studie fra 2009 (3) viste at $74 \%$ av de arvelige tilfellene av porphyria cutanea tarda i Norge skyldtes to hyppig forekommende mutasjoner.

Akutt intermitterende porfyri er i de fleste populasjoner den hyppigst forekommende akutte porfyrisykdommen. Selv om sykdommen arves autosomalt dominant, er det lav klinisk penetrans, og det er antatt at bare $10-20 \%$ av genetisk disponerte individer noensinne vil få symptomgivende sykdom. En ny studie der man har undersøkt insidens av akutt intermitterende porfyri i flere europeiske land ga en kalkulert prevalens (gjennomsnitt basert på insidens i deltakende land i studien) av symptomgivende akutt intermitterende porfyri på $0,5: 100000$ (14), som er betydelig lavere enn vårt estimat $(4: 100000)$ og estimatet fra Sverige $(10: 100000$, her er imidlertid også prediktivt påviste tilfeller uten symptomer inkludert) $(15,16)$. skyldes blant annet en grunnleggermutasjon
Den høye prevalensen i Norge og Sverige som har sitt utspring i Arjeplog i NordSverige, der estimert prevalens er 2 000:100 000 (15). I Saltdal kommune i Nordland, hvor denne mutasjonen også er hyppig forekommende, er prevalensen estimert til 600:100 000 (7). En tilleggsforklaring kan være at man i Norge og Sverige har et bedre tilbud for familieutredning og større kunnskap om sykdommene, hvilket fører til at flere får riktig diagnose.

Det er gjort få studier på diagnostisk forsinkelse ved porfyri, men i studier av erytropoetisk protoporfyri i Sverige (17) og Storbritannia (18) er det rapportert om en forsinkelse på henholdsvis 18 år og 12 år, sammenliknet med 17 år i vår studie. Sykdommen er diagnostisk utfordrende, ikke bare fordi den er svært sjelden, men også fordi den kliniske presentasjonen ofte kan være et lite barn som gråter og er urolig når det er ute i solen, uten at dette følges av tydelige hudforandringer (1). Denne studien inkluderer for få pasienter med erytropoetisk protoporfyri til at vi kan undersøke om diagnosen stilles raskere nå enn før, men studiene fra Sverige og Storbritannia har ikke kunnet vise at dette er endret $(17,18)$.

Behovet for kontroll og oppfølging avgjøres både av type porfyrisykdom og om man har symptomgivende sykdom eller kun er genetisk disponert uten å ha hatt symptomer. Ved de fleste porfyrisykdommene har man mulighet til å forebygge utbrudd eller tilbakefall. Mange pasienter kan derfor ved riktig behandling og oppfølging forbli symptomfrie store deler av livet, og komplikasjoner som hypertensjon, nyresvikt, hepatocellulært karsinom hos pasienter med akutte porfyrisykdommer $(19,20)$ og leversvikt ved erytropoetisk protoporfyri (21) kan oppdages tidlig.

Til tross for at alle som har hatt symptomer anbefales å gå til kontroll årlig (22), oppgir over halvparten av pasientene med symptomgivende akutt intermitterende porfyri og en tredel av pasientene med porphyria cutanea tarda at de aldri gjør det. På bakgrunn av dette utarbeidet NAPOS i 2010 detaljerte diagnosespesifikke retningslinjer for oppfølging og kontroll av porfyripasienter (22).

Det er stort sett samsvar mellom symptomene som norske pasienter rapporterer ved anfall av akutt intermitterende porfyri og det som er funnet $i$ andre studier $(5,23,24)$. Akutte anfall kan utløses av en rekke faktorer, som hormonforandringer (f.eks. menstruasjon), utrygge medikamenter, alkohol, faste/slanking, psykisk og fysisk stress og andre sykdommer (4-6). Medikamentbruk $(40 \%)$ ble hyppigere rapportert som utløsende faktor $i$ vår studie sammenliknet med data fra Sverige $(20 \%)$ (5) og Sør-Afrika (10\%) (6). I tillegg rapporterte $18 \%$ av 
kvinnene i vår studie spesifikt p-piller som utløsende faktor.

Særlig deltakere med akutt intermitterende porfyri og erytropoetisk protoporfyri oppga at de hadde nedsatt livskvalitet på grunn av sykdommen, men funnene bør tolkes med forsiktighet, siden de ikke er basert på en validert metode. Det har tidligere vært rapportert lavere livskvalitet hos pasienter med akutte porfyrisykdommer enn hos friske individer og diabetespasienter (25).

Nyere studier $(17,18)$ har vist at pasienter med erytropoetisk protoporfyri har sterkt redusert livskvalitet, noe som delvis forklares med den lange diagnostiske forsinkelsen, store begrensninger i livsutfoldelse og at det finnes få behandlingsalternativer. Med bakgrunn $\mathrm{i}$ at flere av porfyrisykdommene kan ha lang diagnostisk forsinkelse, kan gi alvorlige og/eller uttalte plager og er avhengig av livslang oppfølging, trengs det nye studier for å kartlegge behovet for oppfølging og hjelp for personer med porfyrisykdom i ulike stadier av livet.

Denne studiens styrke er at den gir en god oversikt over porfyrisykdommer i Norge, da den inkluderer alle porfyripasienter registrert ved NAPOS siden etableringen i 1999. Studien inneholder derfor mange pasienter, til tross for at det dreier seg om sjeldne tilstander. I tillegg er svarprosenten i Norsk porfyriregister relativt høy -70 . Det er ikke gjort frafallsanalyser, men vi ser blant annet at svarprosenten er høyere hos kvinner enn hos menn og at det er høyere svarprosent hos personer med erytropoetisk protoporfyri. Det må imidlertid tas hensyn til at data hentet fra registeret er pasientrapporterte.

Det finnes fortsatt lite systematisk kunnskap om forløpet av de forskjellige porfyrisykdommene og om behandlingseffekt. For mange pasienter er det en stor utfordring å ha en sjelden sykdom i møte med helsevesenet. Norsk porfyriregister vil ved innhenting av systematiske data bidra til utvikling og implementering av retningslinjer som kan føre til bedre praksis. Det er nylig opprettet et felles europeisk porfyriregister som driftes av NAPOS (26). Dette registeret vil kunne favne om et mangedoblet antall personer med porfyrisykdom, noe som vil gi bedre data og dermed igjen et bedre grunnlag for kunnskapsbasert praksis.

\section{Mira Mykletun (f. 1983)}

er human fysiolog og fagkonsulent. Forfatter har fylt ut ICMJE-skjemaet og oppgir ingen interessekonflikter.

\section{Aasne K. Aarsand (f. 1973)}

er spesialist i medisinsk biokjemi og overlege. Forfatter har fylt ut ICMJE-skjemaet og oppgir ingen interessekonflikter.

\section{Egil Støle (f. 1975)}

er cand.scient. i biologi og spesialkonsulent. Forfatter har fylt ut ICMJE-skjemaet og oppgir ingen interessekonflikter.

\section{Jørild Haugen Villanger (f. 1974)}

er cand.scient. i biologi og prosjektkonsulent. Forfatter har fylt ut ICMJE-skjemaet og oppgir ingen interessekonflikter.

\section{Mette C. Tollånes (f. 1973)}

er postdoktor ved Institutt for global helse og samfunnsmedisin, Universitetet i Bergen, og har en bistilling som lege.

Forfatter har fylt ut ICMJE-skjemaet og oppgir ingen interessekonflikter.

\section{Carl Baravelli (f. 1979)}

har en bachelorgrad i Psychological Science fra Australia og er konsulent.

Forfatter har fylt ut ICMJE-skjemaet og oppgir ingen interessekonflikter.

\section{Sverre Sandberg (f. 1950)}

er leder av Nasjonalt kompetansesenter for porfyrisykdommer (NAPOS), leder av Norsk kvalitetsforbedring av laboratorievirksomhet utenfor sykehus (Noklus) og professor ved Institutt for global helse og samfunnsmedisin, Universitetet i Bergen.

Forfatter har fylt ut ICMJE-skjemaet og oppgir ingen interessekonflikter.

\section{Litteratur}

1. Puy H, Gouya L, Deybach JC. Porphyrias. Lancet 2010; 375: 924-37.

2. Aarsand AK. Diagnosing and monitoring the porphyrias. With special emphasis on how to interpre changes in urinary porphobilinogen in acute intermittent porphyria, differentiate sporadic and familial porphyria cutanea tarda and on the performance of porphyria specialist laboratories. Dok toravhandling. Bergen: Universitetet i Bergen, 2012.

3. Aarsand AK, Boman H, Sandberg S. Familial and sporadic porphyria cutanea tarda: characterization and diagnostic strategies. Clin Chem 2009; 55 795-803.

4. Badminton MB, Deacon AC, Elder GH. The porphyrias and other disorders of porphyrin metabolism. I: Burtis CA, Aashwood E, Bruns D, red. Tietz textbook of clinical chemistry and molecular diagnostics. 5. utg. St. Louis, MO: Elsevier Saunders, 2012 $1031-52$

5. Bylesjö I, Wikberg A, Andersson C. Clinical aspects of acute intermittent porphyria in northern Sweden: a population-based study. Scand J Clin Lab Invest 2009; 69: 612-8.

6. Hift RJ, Meissner PN. An analysis of 112 acute porphyric attacks in Cape Town, South Africa: Evidence that acute intermittent porphyria and varie- gate porphyria differ in susceptibility and severity. Medicine (Baltimore) 2005; 84: 48-60.

7. Tollåli G, Nielsen EW, Brekke OL. Akutt intermitterende porfyri. Tidsskr Nor Lægeforen 2002; 122 1102-5.

8. Petersen NE, Brock A. Akutte porfyrisygdomme. Tidsskr Nor Laegeforen 2000; 120: 1421-3.

9. Rossmann-Ringdahl I, Olsson R. Porphyria cutanea tarda in a Swedish population: risk factors and complications. Acta Derm Venereol 2005; 85 337-41.

10. Badenas C, To-Figueras J, Phillips JD et al. Identification and characterization of novel uroporphyrinogen decarboxylase gene mutations in a large series of porphyria cutanea tarda patients and relatives. Clin Genet 2009: 75: 346-53.

11. Brady JJ, Jackson HA, Roberts AG et al. Co-inheritance of mutations in the uroporphyrinogen decarboxylase and hemochromatosis genes accelerates the onset of porphyria cutanea tarda. J Invest Dermatol 2000: 115: 868-74.

12. Méndez M, Poblete-Gutiérrez P, García-Bravo M et al. Molecular heterogeneity of familial porphyria cutanea tarda in Spain: characterization of 10 novel mutations in the UROD gene. Br J Dermatol 2007: 157: $501-7$

13. Christiansen L, Brøns-Poulsen J, Hørder M et al. Expression and characterization of six clinically relevant uroporphyrinogen decarboxylase gene mutations. Scand J Clin Lab Invest 2005; 65: 227-35.

14. Elder G, Harper P, Badminton M et al. The incidence of inherited porphyrias in Europe. J Inheri Metab Dis 2013; 36: 849-57.

15. Andersson C. Thunell S, Floderus Y et al. Diagnosis of acute intermittent porphyria in northern Sweden: an evaluation of mutation analysis and biochemical methods. J Intern Med 1995; 237: $301-8$

16. Andersson C. Acute intermittent porphyria in northern Sweden. A population based study. Umeå: Umeå universitet, 1997

17. Wahlin S, Floderus Y, Stål P et al. Erythropoietic protoporphyria in Sweden: demographic, clinical, biochemical and genetic characteristics. J Intern Med 2011; 269: 278-88

18. Holme SA, Anstey AV, Finlay AY et al. Erythropoietic protoporphyria in the U.K.: clinical features and effect on quality of life. Br J Dermatol 2006; 155: 574-81.

19. Andersson C, Lithner F. Hypertension and renal disease in patients with acute intermittent porphyria. J Intern Med 1994: 236: 169-75.

20. Innala E, Andersson C. Screening for hepatocellular carcinoma in acute intermittent porphyria: a 15-year follow-up in northern Sweden. J Intern Med 2011; 269: 538-45.

21. Anstey AV, Hift RJ. Liver disease in erythropoietic protoporphyria: insights and implications for management. Gut 2007; 56: 1009-18

22. Nasjonalt kompetansesenter for porfyrisykdommer. www.napos.no (1.1.2013).

23. Goldberg A. Acute intermittent porphyria: a study of 50 cases. Q J Med 1959; 28: 183-209.

24. Stein JA, Tschudy DP. Acute intermittent porphyria. A clinical and biochemical study of 46 patients. Medicine (Baltimore) 1970; 49: 1-16.

25. Millward LM, Kelly P, Deacon A et al. Self-rated psychosocial consequences and quality of life in the acute porphyrias. J Inherit Metab Dis 2001; 24: 733-47

26. European Porphyria Network. www. porphyria-europe.org (1.1.2012).

Mottatt 13.5. 2013, første revisjon innsendt 2.11. 2013, godkjent 11.3. 2014. Redaktør: Kristin Viste. 